\title{
The Role of Traditional and Virtual Scaffolding in Developing Speaking Ability of Iranian EFL Learners
}

\author{
Seyyed Hassan Mirahmadi ${ }^{1} \&$ Seyyed Mohammad Alavi $^{2}$ \\ ${ }^{1}$ Department of English, Science and Research Branch, Islamic Azad University, Tehran, Iran \\ ${ }^{2}$ Department of English, University of Tehran, Tehran, Iran \\ Correspondence: Seyyed Hassan Mirahmadi, Faculty of Nautical Sciences, Kharg Island, Boushehr, Iran. Tel: \\ 98-912-498-4548. E-mail: mirahmadi2009@gmail.com
}

\author{
Received: January 22, 2016 Accepted: February 10, 2016 Online Published: March 28, 2016 \\ doi:10.5539/ijel.v6n2p43 \\ URL: http://dx.doi.org/10.5539/ijel.v6n2p43
}

\begin{abstract}
The present study attempted to investigate the effect of the four scaffolding techniques, namely Hard, Soft (Saye \& Brush, 2002), Reciprocal (Holton \& Clarke, 2006), and Virtual (Yelland \& Masters, 2007), on the speaking ability of the Iranian EFL language learners and their fluency, lexicon, grammar and pronunciation. To this end, the four scaffolding techniques were classified into the two groups of Traditional (Hard, Soft and Reciprocal) and technology-mediated (Virtual). 120 Maritime students at Kharg Azad University (IAU-Kharg) were selected as participants based on convenience sampling. At the onset, an Oxford Placement Test was given to the students to place them in the same proficiency level, Intermediate. 10 students were found as outliers who remained as intact members of the groups throughout the study. Eventually, the 110 homogeneous students were randomly assigned to the four scaffolding groups. A pretest of speaking ability was run to the students prior to the scaffolding treatments lasting for 8 weeks (16 sessions). After the treatments, the students completed a posttest of speaking. Having analyzed the data through SPSS software, it was found that under the influence of the four scaffoldings, not only did the Iranian EFL students outperformed in the posttest of speaking, but they also showed a significant improvement in their fluency, grammar, lexicon, and pronunciation. Thus, the findings of this current study extended earlier understandings of scaffolding in an EFL environment and will contribute to the advancement of future courses in terms of their scaffolding pedagogical aspects.
\end{abstract}

Keywords: scaffolding, sociocultural theory, speaking ability, technology-mediated scaffolding, ZPD

\section{Introduction}

For many years, the understanding of foreign language learning difficulties has been a crucial point of interest among foreign language (FL) educators. Great attention has been paid to teaching the literacy skills needed to succeed in tertiary institutions abroad to EFL students (Ferris \& Tagg, 1996, p. 479). Though these studies (Ferris, 1998) have been very helpful to EFL teachers, few have looked beyond reading and writing skills (Ferris \& Tagg, 1996; Iwashita et al., 2008; Kim, 2006). Furthermore, as Ostler (1980) contends, listening and speaking skills are most problematic for EFL students while they study in English-speaking countries.

College/university students engaging in EFL are often intimidated by speaking tasks in English, including both formal presentation and participation in large- or small-group class discussions while they study abroad. Reasons for this hesitation appear to stem from insecurity about linguistic competence and insufficient listening/speaking proficiency required so that they can communicate effectively (Ferris \& Tagg, 1996; Kim, 2006; Ostler, 1980).

Speaking is undeniably the fundamental language skill in language learning and teaching. Richards \& Renandya (2002) assert: "A large percentage of the world's language learners study English in order to develop proficiency in speaking" (p. 201). The fact that mastery of speaking takes priority is also reflected in the tendency of society to deem speaking skill as a measure of one's mastery of English. Nevertheless, students have often complained it is so difficult and demanding to speak well. Developing the students' oral communication strategies and encouraging them to be active members engaged in language learning has long been a formidable issue. In fact, many students consider language fluency to communicate verbally with others often more important than the ability to read or write. They argue that speaking is the most important language skills that need to be controlled, and they assess learning achievement based on mastery of speaking skill (Burnkart, 1998). 
Since the mastery of speaking skills in English is a priority for many second-language or foreign-language learners, they often evaluate their success in language learning as well as the effectiveness of their English course on the basis of how much they feel they have improved in their spoken language proficiency. Oral skills have hardly been neglected in EFL/ESL courses though how best to approach the teaching of oral skills has long been the focus of methodological debate. As Richards (1990) states, teachers and textbooks make use of a variety of approaches, ranging from direct approaches focusing on specific features of oral interaction (e.g., turn-taking, topic management, and questioning strategies) to indirect approaches that create conditions for oral interaction through group work, task work, and other strategies.

Today, efforts in language classrooms ought to concentrate on aural intake through active negotiation of meaning with others (peers or teachers) both in traditional contexts where teachers or peers- preferably more competent ones- work together and give assistance to each other through feedbacks and virtual contexts inn which technology overrules the learning situation. This mutual negotiation of meaning between speakers (peers or teachers) as well as interaction with the available technology trigger the cognitive and sociocognitive processes required for language acquisition to occur (Pica \& Doughty, 1985).

Since the term scaffolding was coined in 1976, there has been a great deal of discussion and debate about what the concept of scaffolding actually means. Scaffolding was traditionally regarded as the interactions between individuals only. In one form, the teacher provided the class with the necessary instructions and assistance or feed-forward in advance (to be called hard scaffolding hereafter in this research) or waiting for the learners' questions and asking for help when they need assistance (hereafter referred to as soft scaffolding).In the same traditional framework, the task of scaffolding and negotiation of meaning can be delegated to the learners themselves to gain assistance from their more competent peers (to be known as reciprocal scaffolding elsewhere from here).

In an elaborate attempt, this research investigated the application of three types of traditional scaffolding known and introduced as hard, soft and reciprocal along with what is known as virtual scaffolding in order to find the possible effects of each technique on developing speaking skill and subskills reported and demonstrated by students majoring in maritime navigation at Kharg University.

More than ninety percent of global trade is carried by sea. As a result it has fostered an interdependency and inter-connectivity between people who would previously have considered themselves completely unconnected. For the maritime industry which facilitates this activity, it is essential that a common working language, namely English, be competently used to safeguard the ship, its crew and the environment in which it sails.

English has been set as the language of the sea at an international level and it is used in all situations such as ship-to-ship, ship-to-shore and between maritime personnel. This is what this study agrees with not only the English language but the oral communication strategies that should be used on board. In addition, a careful study identified that $80 \%$ of maritime accidents are down to human factors, of which failure of communication represents one-third. On the other hand, the International Maritime Organization (IMO) has also underlined the importance of effective communication in an International Seminar as a crucial issue for Marine Safety. This study investigated the ways to help improve the speaking ability and oral communication strategies among maritime students on Kharg Island so as to reduce the number of maritime accidents caused by the human factor due to communication failures which have become a problem in the maritime industry.

With the growing need for seafarer communicative competence, Iran seems to fall behind in English education and training at its maritime institutions in spite of much effort and time allotted. In Benton's (2003) opinion, most young seafarers still face language problems in the aspects of English speaking and listening. He further comments that besides speaking incompetency, seafarers have to gain oral communication strategies which have not been covered in maritime English teaching syllabus.

Currently, the purpose of English language as a means of communication is ignored in teaching and learning at Marine Institutes (Rojo-Laurilla, 2011). As collected from a number of long discussions with the competent captains and engineers who have been long at sea and teaching for more than a decade at Kharg University, as well as friendly chats with Marine students there, cadets at Maritime University of Kharg were found to have low learning motivation. Most of them lack the confidence to equip themselves with oral English skills namely listening and speaking. Other students were reported to lack enough courage to speak English publicly, especially with foreigners. They worry about any mistakes they can make during the conversation. As a result, during the learning process they are silent and have barriers in speaking English psychologically. Hence, this blocks their way to be competent seafarers.

Furthermore, the researcher got the inspiration for the research from the fact that there hasn't been a 
well-designed and elaborate teaching methodology to enhance the learners' speaking and listening abilities. Students keep complaining that in their content-based classes, courses designed and assigned for their major, do not give them the opportunity to get exposed to authentic English as taken from real or lifelike situations and that their ears are not accustomed to English utterances at normal speed.

The above-mentioned shortcomings in the oral ability of the marine students at Kharg University encouraged the researcher to carry out a remedial project in line with Vygotsky an approach to learning- hereto say scaffoldingto see if it can help the students develop their oral communication ability to overcome their long-established communication barriers particularly with the focus on their speaking ability.

\section{Scaffolding}

According to Donato (1994), scaffolding is a concept derived from cognitive psychology and L1 research. It states that in a social interaction, a knowledgeable participant can create a context by means of speech and supportive conditions in which the student (novice) can participate in and extend current skills and knowledge to a high level of competence. In an educational context, however, scaffolding is an instructional structure whereby the teacher models the desired learning strategy or task then gradually shifts responsibility to the students.

Rogoff (1990), cited in Donato (1994), holds the view that scaffolding implies the expert's active stance towards continual revisions of the scaffolding in response to the emerging capabilities of the learner, and a learner's error or limited capabilities can be a signal for the adult to upgrade the scaffolding. As the learner begins to take on more responsibility for the task, the adult dismantles the scaffold indicating that the child has benefited from the assisted performance and internalized the problem-solving processes provided by the previous scaffolded episode. Wertsch(1979a), cited in Donato (1994), claims that scaffolded performance is a dialogically constituted interpsychological mechanism that promotes the learner's internalization of knowledge co-constructed in shared activity. Donato (1994) advocates that in an L2 classroom, collaborative work among language learners provides the same opportunity for scaffolded help as in expert-novice relationships in the everyday setting. The study of scaffolding in L2 research, according to Donato, has focused exclusively on how language teachers provide guided assistance to learners.

So far studies on scaffolding in individuals and groups have been looked at. In the following section, however, ideas behind cooperative learning will be reviewed. The theoretical bases of cooperative learning can be related to behaviorist theory, cognitive-developmentalist theory, and social-interdependence theories (Johnson \& Johnson, \& Smith, 1998).

\section{Virtual Approach to Scaffolding: Technology-Mediated}

A number of attempts have been made by various researchers to classify and taxonomize the types or applications of scaffolding that may be used in technology-mediated learning environments. According to Winnips \& McLoughlin (2000), for example, applications of scaffolding can be categorized according to who regulates the scaffolding (e.g., the teacher, the software, peers, the learner him/herself), the technology used, the pedagogy used, or the intended learning outcome.

According to Oliver \& Herrington (2003), with the move to technology-mediated learning settings such as the World Wide Web, this form of teaching has continued and many examples of Web courses share these characteristics (e.g., Dehoney \& Reeves, 1999). Much of the instructional design that has been applied to Web-based learning environments has been guided by the principles of instructional systems design, an approach widely used for the development of learning materials prepared for correspondence and print-based forms of flexible delivery (Ragan \& Smith, 1996). They further contend that these approaches are based on the notions that learning occurs primarily through the consequences of internal and external conditions relating to the learner and the instruction.

Whereas technology can play a significant part in developing and enhancing language learning, the effective results of any technological device depend on the knowledge and expertise of the qualified language teacher who utilizes, manages and facilitates the language learning environment (Patel, 2011). Patel continues, in some schools and universities, however, administrators have adopted technology to the extent that it has driven the language curriculum and even replaced qualified language teachers.

Technology aligned to learning styles has been used to engage students and support learning (Larsen, 1992). Technology tools also serve to enable students through creation of learning objects and extend learning by providing learning by doing or learning by seeing experiences (Bruner \& Olson, 1973). They also affect the manner in which students respond to, contribute to, and demonstrate understanding of content (Chen, et al., 2005). 


\section{Traditional Approaches to Scaffolding: Hard, Soft and Reciprocal}

In our research project, we conceptualize two main types of scaffolded support, Traditional and Technical, as the main variables. Traditional scaffoldings include Soft and hard scaffoldings (Saye \& Brush, 2002) as well as reciprocal scaffolding (Holton and Clarke, 2006). Each theory will be defined briefly below:

Hard scaffolding, in contrast, is a static support that can be anticipated and planned in advance based upon typical student difficulties with a task (Saye \& Brush, 2002). The teacher gives explanations and the necessary feedback to the learners depending on his teaching experiences and anticipating the learners' problems.

Soft scaffolding has been referred to as dynamic, situation-specific aid provided by a teacher to help with the learning process. Such scaffolding requires teachers to continuously diagnose the understandings of learners and provide timely support based on student responses (Saye \& Brush, 2002). This type of assistance is generally provided on-the-fly, where the teacher monitors the progress students are making while engaged in a learning activity and intervenes when support or guidance is needed.

Within the process of Reciprocal Scaffolding, as stated by Holton \& Clarke (2006), the students are working together with their peers. They exchange information in their search for knowledge. This is a trial and error phase for them in their efforts to construct knowledge. At this stage, the students seem not to have mastered the materials/knowledge yet.

According to Holton \& Clarke (2006), reciprocal scaffolding is a scaffolding technique that takes the form of a dialogue between teachers and students or students and their peers that facilitates learning. This technique is thought to promote students' participation in cooperative learning. Holton \& Clarke explain further that a reciprocal approach provides students with four specific reading strategies that are actively and consciously used to support comprehension: Questioning, Clarifying, Summarizing, and Predicting. Palincsar (1986) believes the purpose of reciprocal teaching is to facilitate a group effort between teacher and students as well as among students in the task of bringing meaning to the text.

The present study finds its roots in the speaking incompetency of the marine cadets studying at Kharg University due to lack of attention to the students' urgent need for developing a sufficient speaking ability and oral communication strategies for further communication at sea in foreign contexts. In line with the research plan, the following questions were targeted as follows:

1) Do the scaffolding contexts have any statistically significant effects on the fluency of the Iranian EFL learners?

2) Do the scaffolding contexts have any statistically significant effects on the lexicon of the Iranian EFL learners?

3) Do the scaffolding contexts have any statistically significant effects on the grammar of the Iranian EFL learners?

4) Do the scaffolding contexts have any statistically significant effects on the pronunciation of the Iranian EFL learners?

Prior to the accomplishment of the project and based on the developed research questions above, the following hypotheses were proposed:

H01 The four scaffolding contexts do not have any statistically significant effects on the fluency of the Iranian EFL learners.

H02 The four scaffolding contexts do not have any statistically significant effects on the lexicon of the Iranian EFL learners.

H03 The four scaffolding contexts do not have any statistically significant effects on the grammar of the Iranian EFL learners.

H04 The four scaffolding contexts do not have any statistically significant effects on the pronunciation of the Iranian EFL learners.

\section{Research Methodology}

\subsection{Design}

After the selection of the subjects based on convenience sampling, the research took a quasi-experimental design in two forms: First, it followed a One-Group Pretest-Posttest Design in which all the participants were assigned to four experimental or treatment groups, namely Hard, Soft, Reciprocal, and Virtual. The assignment of the 
participants was random.

The research also implemented a second form of quasi-experimental design called time-series. Between the pretest and posttest of speaking, four successive tests of speaking were conducted at equal intervals. All participants had to attend an interview on the completion of each two units which took two weeks or 4 sessions.

\subsection{Procedures}

Having conducted a proficiency test of Oxford University (OPT), 110 students were randomly assigned to the four scaffolding groups with the 10 outliers remaining intact among others. At the onset of the research project, an oral pre-test of speaking ability was administered to the selected nominees to keep a record of their speaking ability that was later compared with the post-test results.

Following an inter-rater scoring process, in addition to the researcher-teacher, a captain proficient in English having an experience of more than 20 years at sea and in foreign countries was briefed and assigned responsible for administering and scoring the interviews. The performances were scored following an analytical procedure (See Appendix C for IELTS Speaking Band Descriptors; University of Cambridge ESOL Examination: Public Version) incorporating the four components of fluency and coherence, lexical resource, grammatical range and accuracy, and pronunciation.

Students were given treatments within a period of 8 weeks- 16 sessions. The textbook covered contained 8 units each of which was taught in two sessions-one week. A test of speaking ability was administered after the completion of each two units. Therefore, a number of 4 tests of speaking ability were run with a two-week interval. At the end of the treatment sessions, a posttest of speaking ability was conducted to all the students in the four groups the results of which were compared with those of the pretest.

\subsection{Participants}

There were a total number of 120 male sophomore students majoring in Maritime Navigation enrolled in their first conversation course with the researcher in the year 2014-2015 academic years. Since conversation courses provided for the students are extracurricular, many of the students are not motivated to attend all the sessions. Participants were not the local residents of the Island, which made it hard for the researcher to have them attend all the treatment sessions.

Since there were no female students majoring in Maritime Navigation, the research project was run with male participants only, not counting the gender of the participants as a variable. As the Maritime students had started their studies soon after high school, they were the same age (19 to 20). Prior to the study, it was made sure that none of the participants had any experience of living in an English-speaking country having a noticeable command of English speaking or listening.

Having conducted the Oxford Placement Test (OPT) for the two purposes of homogenizing the students and placing them in the two levels of High and Low Intermediate, a number of 10 students were marked as outliers and thus remained intact throughout the research process. The research, therefore, went on with 110 students as participants of the study. The resulted 110 participating subjects were 55 Low Intermediate (LI) and 55 High Intermediate (HI) categorized into four scaffold groups (Table 1).

Table 1. Classification of participants in terms of groups and proficiency

\begin{tabular}{lllll}
\hline $\begin{array}{l}\text { Level } \\
\text { Group }\end{array}$ & LI & HI & Intact & Total \\
\hline Hard & 13 & 13 & 4 & 30 \\
Soft & 14 & 14 & 2 & 30 \\
Reciprocal & 14 & 14 & 2 & 30 \\
Virtual & 14 & 14 & 2 & 30 \\
\hline
\end{tabular}

\subsection{Instruments}

In the process of the research project the required data were gathered at different junctures prior to, within and after the treatments through employing the following instruments:

Interviews: Before and after the treatments, all participants were invited to attend the two oral performance tests designed for the purpose of the study and in line with the research questions. The questions and topics aimed for this purpose were developed and prepared by the researcher based on the materials of the textbook (Iran Language Institutes English Series). Between the pre and post speaking tests, four other oral tests were run to the 
participants at equal intervals (every two weeks, upon the completion of two chapters). The questions prepared for the interviews were made on the contents of the two chapters of the textbook taught, the learning objectives of which will be presented fully in the following section.

Textbook: All the treatment sessions were conducted using the textbook at Pre-intermediate level developed and designed by the Iran Language Institute (ILI) where the researcher has been teaching for almost two decades continuously. The selected textbook is designed into eight units comprising a vocabulary list, a conversation, a reading passage, grammar notes and drills followed by a listening task at the end. Each unit was accomplished in two sessions. The ILI English Series follows an integrated approach to teaching English, the book focuses on grammar and writing, reading, listening and speaking at the same time. From Basic to Intermediate levels, much attention has been given to listening and speaking skills; little attention to reading, and the least attention to writing. The main objectives of the courses for Basic to Intermediate levels are improving the learners' listening and speaking abilities, the fact which motivated the researcher to choose and implement the textbook for the purpose of the study.

Technology: The feasibility and applicability of the technological tools and, of course, the availability and accessibility of them led the researcher to take advantages of Telegram Messenger in the virtual scaffolding context of teaching speaking. Telegram is an instant messaging system focusing on privacy and multi-platform availability. Telegram clients exist for both mobile (Android, iOS, Windows Phone) and desktop systems (Windows, OS X, Linux). Telegram users can exchange messages encrypted end-to-end, self-destructing messages, along with photos, videos, stickers, and files of any type up to $1.5 \mathrm{~GB}$ in size.

\section{Results and Discussion}

\subsection{Pretest of Speaking}

A one-way analysis of variances was run to compare the hard, soft, reciprocal and virtual groups' means on the pretest of speaking in order to prove that they were at the same level of speaking ability prior to the main study. Before discussing the results it should be mentioned that the assumption of homogeneity of variances was met $($ Levene's $\mathrm{F}(3,108)=.631, \mathrm{P}=.597)($ Table 2$)$.

Table 2. Levene's test of equality of error variances

\begin{tabular}{llll}
\hline $\mathbf{F}$ & df1 & df2 & Sig. \\
\hline .631 & 3 & 108 & .597 \\
\hline
\end{tabular}

As displayed in Table 4 the hard $(\mathrm{M}=29.86, \mathrm{SD}=5.54)$, reciprocal $(\mathrm{M}=27.14, \mathrm{SD}=6.53)$, virtual $(\mathrm{M}=27.11, \mathrm{SD}$ $=5.38)$ and $\operatorname{soft}(\mathrm{M}=28, \mathrm{SD}=6.39)$ groups had almost the same means on the pretest of speaking.

Table 3. Descriptive statistics, pretest of speaking by groups

\begin{tabular}{|c|c|c|c|c|c|c|}
\hline & $\mathrm{N}$ & Mean & Std. Deviation & Std. Error & $\begin{array}{l}\text { 95\% Confidence } \\
\text { Interval for Mean } \\
\text { Lower Bound }\end{array}$ & Upper Bound \\
\hline$\overline{\text { Hard }}$ & 28 & 29.86 & 5.549 & 1.049 & 27.71 & 32.01 \\
\hline Reciprocal & 28 & 27.14 & 6.530 & 1.234 & 24.61 & 29.68 \\
\hline Virtual & 28 & 27.11 & 5.384 & 1.017 & 25.02 & 29.19 \\
\hline Soft & 28 & 28.00 & 6.394 & 1.208 & 25.52 & 30.48 \\
\hline Total & 112 & 28.03 & 6.010 & .568 & 26.90 & 29.15 \\
\hline
\end{tabular}

Based on the results displayed in Table $4\left(\mathrm{~F}(3,108)=1.29, \mathrm{P}=.279, \omega^{2}=.008\right.$ representing a weak effect size $)$ it can be concluded that there were not any significant differences between the means of the four groups on the pretest of speaking. Thus it can be claimed that they were homogenous in terms of their speaking ability prior to the main study. 
Table 4. Box's test of equality of covariance matrices

\begin{tabular}{ll}
\hline Box's M & 46.783 \\
F & 1.454 \\
df1 & 30 \\
df2 & 32069.041 \\
Sig. & .052 \\
\hline
\end{tabular}

\subsection{Pretests of Speaking Components}

A multivariate ANOVA (MANOVA) was run to compare the four groups' means on the pretests of fluency, lexicon, grammar and pronunciation in order to prove that they were homogenous in terms of the speaking fluency, lexicon, grammar and pronunciation. Before discussing the results it should be mentioned that the assumptions of homogeneity of variances was met. As displayed in Table 5 the probabilities associated with the Levene's F-values were all higher than .05.

Table 5. Levene's test of equality of error variances

\begin{tabular}{lllll}
\hline & F & df1 & df2 & Sig. \\
\hline PreFlu & 1.576 & 3 & 108 & .199 \\
PreLex & .621 & 3 & 108 & .603 \\
PreGram & 1.172 & 3 & 108 & .324 \\
PrePro & .958 & 3 & 108 & .416 \\
\hline
\end{tabular}

The assumption of homogeneity of covariance matrices was also met (Box's $\mathrm{M}=46.78, \mathrm{P}>.001$ ) (Table 4).

Based on the results displayed in Table 7 and Table 8, it can be claimed that;

A: There were not any significant difference between hard $(\mathrm{M}=7.78, \mathrm{SE}=.31)$, reciprocal $(\mathrm{M}=7.07, \mathrm{SE}=.31)$, virtual $(\mathrm{M}=6.71, \mathrm{SE}=.31)$ and soft $(\mathrm{M}=7.10, \mathrm{SE}=.31)$ groups' means on pretest of speaking fluency ( $\mathrm{F}(3$, $108)=2.06, p=.109$, Partial $\eta 2=.054$ representing a weak effect size). Thus it can be claimed that the four groups were homogenous in terms of their speaking fluency prior to the main study.

$B$ : There were not any significant difference between hard $(\mathrm{M}=7.25, \mathrm{SE}=.32)$, reciprocal $(\mathrm{M}=6.53, \mathrm{SE}=.32)$, virtual $(\mathrm{M}=7.07, \mathrm{SE}=.32)$ and soft $(\mathrm{M}=7.10, \mathrm{SE}=.32)$ groups' means on pretest of speaking lexicon ( $\mathrm{F}(3$, $108)=.943, p=.423$, Partial $\eta 2=.026$ representing a weak effect size). Thus it can be claimed that the four groups were homogenous in terms of their speaking lexicon prior to the main study.

Table 6. Descriptive statistics; pretests of speaking components by groups

\begin{tabular}{llllll}
\hline Dependent Variable & Group & Mean & Std. Error & \multicolumn{2}{c}{$95 \%$ Confidence Interval } \\
& & & & Lower Bound & Upper Bound \\
\hline \multirow{4}{*}{ PreFlu } & Hard & 7.786 & .311 & 7.169 & 8.403 \\
& Reciprocal & 7.071 & .311 & 6.454 & 7.688 \\
& Virtual & 6.714 & .311 & 6.097 & 7.331 \\
& Soft & 7.107 & .311 & 6.490 & 7.724 \\
PreLex & Hard & 7.250 & .323 & 6.611 & 7.175 \\
& Reciprocal & 6.536 & .323 & 5.896 & 7.711 \\
& Virtual & 7.071 & .323 & 6.432 & 7.747 \\
PreGram & Soft & 7.107 & .323 & 6.468 & 7.404 \\
& Hard & 7.786 & .312 & 7.168 & 7.261 \\
& Reciprocal & 7.143 & .312 & 6.525 & 7.761 \\
PrePro & Virtual & 6.643 & .312 & 6.025 & 7.650 \\
& Soft & 7.143 & .312 & 6.525 & 7.007 \\
& Hard & 7.036 & .310 & 6.422 & 7.293 \\
\hline
\end{tabular}

$\mathrm{C}$ : There were not any significant difference between hard $(\mathrm{M}=7.78, \mathrm{SE}=.31)$, reciprocal $(\mathrm{M}=7.14, \mathrm{SE}=.31)$, virtual $(\mathrm{M}=6.64, \mathrm{SE}=.31)$ and soft $(\mathrm{M}=7.14, \mathrm{SE}=.31)$ groups' means on pretest of speaking grammar ( $\mathrm{F}(3$, $108)=2.25, \mathrm{p}=.086$, Partial $\eta 2=.059$ representing a weak effect size). Thus it can be claimed that the four 
groups were homogenous in terms of their speaking grammar prior to the main study.

$\mathrm{D}$ : There were not any significant difference between hard $(\mathrm{M}=7.03, \mathrm{SE}=.31)$, reciprocal $(\mathrm{M}=6.39, \mathrm{SE}=.31)$, virtual $(\mathrm{M}=6.67, \mathrm{SE}=.31)$ and soft $(\mathrm{M}=6.63, \mathrm{SE}=.31)$ groups' means on pretest of speaking pronunciation ( $\mathrm{F}$ $(3,108)=.730, p=.536$, Partial $\eta 2=.020$ representing a weak effect size). Thus it can be claimed that the four groups were homogenous in terms of their speaking pronunciation prior to the main study.

Table 7. Tests of between-subjects effects; pretests of speaking components by groups

\begin{tabular}{llllllll}
\hline Source & Dependent Variable & $\begin{array}{l}\text { Type III Sum of } \\
\text { Squares }\end{array}$ & df & Mean Square & F & $\begin{array}{c}\text { Sig. } \\
\text { Partial Eta } \\
\text { Squared }\end{array}$ \\
\hline Group & PreFlu & 16.813 & 3 & 5.604 & 2.066 & .109 & .054 \\
& PreLex & 8.241 & 3 & 2.747 & .943 & .423 & .026 \\
& PreGram & 18.429 & 3 & 6.143 & 2.257 & .086 & .059 \\
& PrePro & 5.884 & 3 & 1.961 & .730 & .536 & .020 \\
Error & PreFlu & 292.964 & 108 & 2.713 & & & \\
& PreLex & 314.750 & 108 & 2.914 & & & \\
& PreGram & 294.000 & 108 & 2.722 & & & \\
\multirow{5}{*}{ Total } & PrePro & 290.179 & 108 & 2.687 & & & \\
& PreFlu & 6067.000 & 112 & & & & \\
& PreLex & 5797.000 & 112 & & & & \\
& PreGram & 6084.000 & 112 & & & \\
& PrePro & 5305.000 & 112 & & & \\
\hline
\end{tabular}

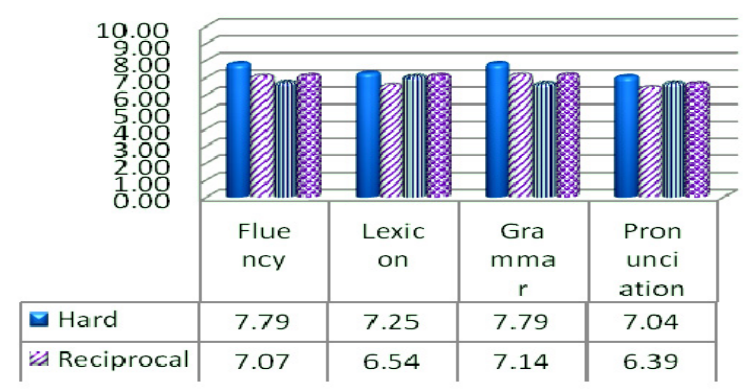

Figure 1. Pretests of speaking components by groups

A multivariate ANOVA (MANOVA) was run to compare the four groups' means on the posttests of fluency, lexicon, grammar and pronunciation in order to probe the second major research question and its components. Before discussing the results it should be mentioned that the assumptions of homogeneity of variances was. As displayed in Table 9 the probabilities associated with the Levene's F-values were all higher than .05 .

Table 8. Levene's test of equality of error variances

\begin{tabular}{lllll}
\hline & F & df1 & df2 & Sig. \\
\hline PreFlu & .381 & 3 & 108 & .767 \\
PreLex & .376 & 3 & 108 & .771 \\
PreGram & 2.224 & 3 & 108 & .089 \\
PrePro & .229 & 3 & 108 & .876 \\
\hline
\end{tabular}

The assumption of homogeneity of covariance matrices was also met (Box's $M=37.79, \mathrm{P}>.001)$ (Table 9). 
Table 9. Box's test of equality of covariance matrices

\begin{tabular}{ll}
\hline Box's M & 37.798 \\
F & 1.175 \\
df1 & 30 \\
df2 & 32069.041 \\
Sig. & .234 \\
\hline
\end{tabular}

Based on the results displayed in Table 11, Table 12 and Table 13 it can be claimed that;

A: There were a significant difference between hard $(\mathrm{M}=11.25, \mathrm{SE}=.64)$, reciprocal $(\mathrm{M}=9.25, \mathrm{SE}=.64)$, virtual $(\mathrm{M}=9.28, \mathrm{SE}=.64)$ and soft $(\mathrm{M}=8.39, \mathrm{SE}=.64)$ (Table 11) groups' means on posttest of speaking fluency $(\mathrm{F}(3,108)=3.47, \mathrm{p}=.019$, Partial $\eta 2=.088$ representing a moderate to large effect size). Thus it can be claimed that the minor null-hypothesis $2-1$ was rejected. The scaffolding contexts had statistically significant effects on the fluency of the Iranian EFL learners.

The results of post-hoc Scheffe's tests indicated that the hard group $(M=11.25)$ significantly outperformed the soft group $(\mathrm{M}=8.39)(\mathrm{MD}=2.86, \mathrm{p}=.025)$ on the posttest of fluency. There were not any significant differences between other comparisons.

$B$ : There were a significant difference between hard $(M=11.03, S E=.60)$, reciprocal $(M=11.03, S E=.60)$, virtual $(\mathrm{M}=9, \mathrm{SE}=.60)$ and soft $(\mathrm{M}=8.53, \mathrm{SE}=.60)$ (Table 11) groups' means on posttest of speaking lexicon $(\mathrm{F}(3,108)=7.50, \mathrm{p}=.000$, Partial $\eta 2=.172$ representing a large effect size) (Table 12). Thus it can be claimed that the minor null-hypothesis 2-2 was rejected. The scaffolding contexts had statistically significant effects on the lexicon of the Iranian EFL learners.

The results of post-hoc Scheffe's tests indicated that

B-1: The hard group $(M=12.03)$ significantly outperformed the soft group $(M=8.53)(M D=3.50, p=.001)$ on the posttest of lexicon.

$B-2$ : The hard group $(M=12.03)$ significantly outperformed the virtual group $(M=9)(M D=3.04, p=.008)$ on the posttest of lexicon.

B-3: The reciprocal group $(M=11.03)$ significantly outperformed the soft group $(M=8.53)(M D=2.50, p$ $=.045)$ on the posttest of lexicon.

There were not any significant differences between other comparisons.

Table 10. Descriptive statistics; pretests of speaking components by groups

\begin{tabular}{llllll}
\hline Dependent Variable & Group & Mean & Std. Error & \multicolumn{2}{c}{$95 \%$ Confidence Interval } \\
& & & & Lower Bound & Upper Bound \\
\hline PostFlu & Hard & 11.250 & .649 & 9.963 & 12.537 \\
& Reciprocal & 9.250 & .649 & 7.963 & 10.537 \\
& Virtual & 9.286 & .649 & 7.999 & 10.573 \\
PostLex & Soft & 8.393 & .649 & 7.106 & 9.680 \\
& Hard & 12.036 & .606 & 10.834 & 13.237 \\
& Reciprocal & 11.036 & .606 & 9.834 & 10.237 \\
PostGram & Virtual & 9.000 & .606 & 7.799 & 9.737 \\
& Soft & 8.536 & .606 & 7.334 & 18.511 \\
& Hard & 17.000 & .762 & 15.489 & 16.690 \\
\multirow{4}{*}{ PostPro } & Reciprocal & 15.179 & .762 & 13.667 & 15.011 \\
& Virtual & 13.500 & .762 & 11.989 & 13.404 \\
& Soft & 11.893 & .762 & 10.382 & 13.651 \\
& Hard & 12.393 & .635 & 11.134 & 10.437 \\
& Reciprocal & 9.179 & .635 & 7.920 & 9.616 \\
\hline
\end{tabular}

$\mathrm{C}$ : There were a significant difference between hard $(\mathrm{M}=17, \mathrm{SE}=.76)$, reciprocal $(\mathrm{M}=15.17, \mathrm{SE}=.76)$, virtual $(\mathrm{M}=13.50, \mathrm{SE}=.76)$ and soft $(\mathrm{M}=11.89, \mathrm{SE}=.76)$ (Table 11) groups' means on posttest of speaking grammar $(\mathrm{F}(3,108)=8.29, \mathrm{p}=.000$, Partial $\eta 2=.187$ representing a large effect size) (Table 11). Thus it can be claimed that the minor null-hypothesis $2-3$ was rejected. The scaffolding contexts had statistically significant effects on the grammar of the Iranian EFL learners. 
The results of post-hoc Scheffe's tests indicated that

$\mathrm{C}-1$ : The hard group $(\mathrm{M}=17)$ significantly outperformed the soft group $(\mathrm{M}=11.89)(\mathrm{MD}=5.11, \mathrm{p}=.000)$ on the posttest of grammar.

$\mathrm{C}-2$ : The hard group $(\mathrm{M}=17)$ significantly outperformed the virtual group $(\mathrm{M}=13.50)(\mathrm{MD}=3.50, \mathrm{p}=.018)$ on the posttest of grammar.

C-3: The reciprocal group $(M=15.17)$ significantly outperformed the soft group $(M=11.89)(M D=3.29, p$ $=.030)$ on the posttest of grammar.

There were not any significant differences between other comparisons.

Table 11. Tests of between-subjects effects; pretests of speaking components by groups

\begin{tabular}{llllllll}
\hline Source & Dependent Variable & Type III Sum of Squares & $\mathrm{df}$ & Mean Square & $\mathrm{F}$ & Sig. & Partial Eta Squared \\
\hline Group & PreFlu & 122.884 & 3 & 40.961 & 3.470 & .019 & .088 \\
& PreLex & 231.527 & 3 & 77.176 & 7.503 & .000 & .172 \\
& PreGram & 404.929 & 3 & 134.976 & 8.293 & .000 & .187 \\
& PrePro & 406.750 & 3 & 135.583 & 12.013 & .000 & .250 \\
Error & PreFlu & 1274.893 & 108 & 11.805 & & & \\
& PreLex & 1110.893 & 108 & 10.286 & & & \\
& PreGram & 1757.786 & 108 & 16.276 & & & \\
& PrePro & 1218.929 & 108 & 11.286 & & & \\
& PreFlu & 11601.00 & 112 & & & & \\
& PreLex & 12885.00 & 112 & & & & \\
& PreGram & 25364.00 & 112 & & & & \\
& PrePro & 11320.00 & 112 & & &
\end{tabular}

$\mathrm{D}$ : There were a significant difference between hard $(\mathrm{M}=12.39, \mathrm{SE}=.63)$, reciprocal $(\mathrm{M}=9.17, \mathrm{SE}=.63)$, virtual $(\mathrm{M}=8.35, \mathrm{SE}=.63)$ and soft $(\mathrm{M}=7.28, \mathrm{SE}=.63)$ (Table 4.15) groups' means on posttest of speaking pronunciation $(\mathrm{F}(3,108)=12.01, \mathrm{p}=.000$, Partial $\eta 2=.250$ representing a large effect size) (Table 12). Thus it can be claimed that the minor null-hypothesis $2-4$ was rejected. The scaffolding contexts had statistically significant effects on the pronunciation of the Iranian EFL learners.

The results of post-hoc Scheffe's tests indicated that

Table 12. Multiple comparisons; posttests of components of speaking by groups

\begin{tabular}{|c|c|c|c|c|c|c|c|}
\hline \multirow[b]{2}{*}{ Dependent Variable } & \multirow[b]{2}{*}{ (I) Group } & \multirow[b]{2}{*}{ (J) Group } & \multirow{2}{*}{$\begin{array}{l}\text { Mean Difference } \\
(\mathrm{I}-\mathrm{J})\end{array}$} & \multirow{2}{*}{ Std. Error } & \multirow{2}{*}{ Sig. } & \multicolumn{2}{|c|}{$95 \%$ Confidence Interval } \\
\hline & & & & & & Lower Bound & Upper Bound \\
\hline \multirow{7}{*}{ PostFlu } & \multirow{3}{*}{ Hard } & Reciprocal & 2.00 & .918 & .198 & -.61 & 4.61 \\
\hline & & Virtual & 1.96 & .918 & .212 & -.64 & 4.57 \\
\hline & & Soft & $2.86^{*}$ & .918 & .025 & .25 & 5.47 \\
\hline & Reciprocal & Soft & .86 & .918 & .832 & -1.75 & 3.47 \\
\hline & \multirow{3}{*}{ Virtual } & Reciprocal & .04 & .918 & 1.000 & -2.57 & 2.64 \\
\hline & & Soft & .89 & .918 & .814 & -1.72 & 3.50 \\
\hline & & Reciprocal & 1.00 & .857 & .715 & -1.43 & 3.43 \\
\hline \multirow{6}{*}{ PostLex } & \multirow[t]{2}{*}{ Hard } & Virtual & $3.04^{*}$ & .857 & .008 & .60 & 5.47 \\
\hline & & Soft & $3.50^{*}$ & .857 & .001 & 1.07 & 5.93 \\
\hline & \multirow[b]{2}{*}{ Reciprocal } & Virtual & 2.04 & .857 & .137 & -.40 & 4.47 \\
\hline & & Soft & $2.50^{*}$ & .857 & .042 & .07 & 4.93 \\
\hline & Virtual & Soft & .46 & .857 & .961 & -1.97 & 2.90 \\
\hline & \multirow{3}{*}{ Hard } & Reciprocal & 1.82 & 1.078 & .419 & -1.24 & 4.88 \\
\hline \multirow{5}{*}{ PostGram } & & Virtual & $3.50^{*}$ & 1.078 & .018 & .44 & 6.56 \\
\hline & & Soft & $5.11^{*}$ & 1.078 & .000 & 2.04 & 8.17 \\
\hline & \multirow{2}{*}{ Reciprocal } & Virtual & 1.68 & 1.078 & .492 & -1.38 & 4.74 \\
\hline & & Soft & $3.29^{*}$ & 1.078 & .030 & .22 & 6.35 \\
\hline & Virtual & Soft & 1.61 & 1.078 & .530 & -1.46 & 4.67 \\
\hline \multirow{6}{*}{ PostPro } & \multirow{3}{*}{ Hard } & Reciprocal & $3.21^{*}$ & .898 & .007 & .66 & 5.76 \\
\hline & & Virtual & $4.04^{*}$ & .898 & .000 & 1.49 & 6.59 \\
\hline & & Soft & $5.11^{*}$ & .898 & .000 & 2.56 & 7.66 \\
\hline & \multirow{2}{*}{ Reciprocal } & Virtual & .82 & .898 & .840 & -1.73 & 3.37 \\
\hline & & Soft & 1.89 & .898 & .224 & -.66 & 4.44 \\
\hline & Virtual & Soft & 1.07 & .898 & .701 & -1.48 & 3.62 \\
\hline
\end{tabular}

Note. The mean difference is significant at the .05 level. 
D-1: The hard group $(M=12.13)$ significantly outperformed the soft group $(\mathrm{M}=7.28)(\mathrm{MD}=5.11, \mathrm{p}=.000)$ on the posttest of pronunciation.

D-2: The hard group $(M=12.13)$ significantly outperformed the virtual group $(M=8.35)(M D=4.04, p=.000)$ on the posttest of pronunciation.

D-3: The hard group $(M=12.13)$ significantly outperformed the reciprocal group $(M=9.17)(M D=3.21, p$ $=.007)$ on the posttest of pronunciation.

There were not nay significant differences between other comparisons.

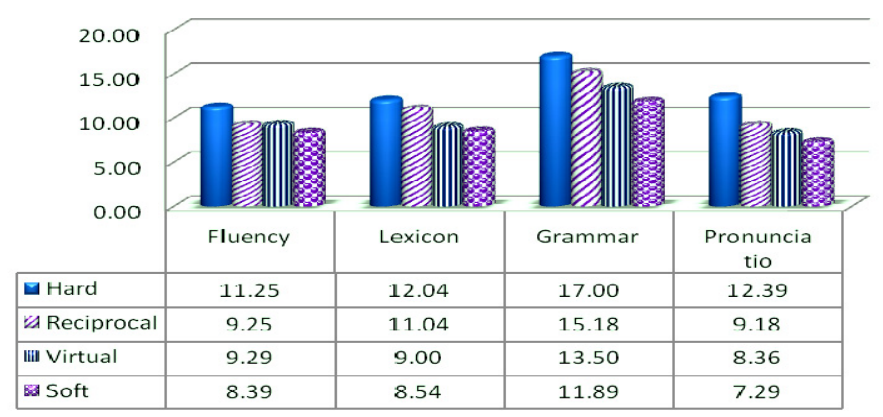

Figure 2. Posttests of speaking components by groups

Through running a one-way analysis of variances (ANOVA), it was found that there were significant differences between the means of the four groups on the posttest of speaking. In other words, the study showed a significant difference in the speaking abilities of the students in the four scaffolding groups. By comparing the means of the pretest and posttest of speaking, it is evident that all the four scaffolding groups showed a significant improvement in their speaking abilities.

This study also focused on the role scaffolding in improving the subskills of speaking referred to as fluency, lexicon, grammar accuracy, and pronunciation. Based on the data analyses, the following findings were reported:

It was shown that there were significant differences between hard, reciprocal, virtual, and soft groups' means on posttest of speaking fluency, proving that the scaffolding contexts had statistically significant effects on the fluency of the Iranian EFL learners. The results also indicated that the hard group significantly outperformed the soft group on the posttest of fluency. There were not any significant differences between other comparisons though.

In terms of lexicon, the study showed significant differences between the lexical abilities of the four scaffolding groups on the posttest. The results revealed that the hard and the reciprocal groups significantly outperformed the soft and virtual ones. No other significant differences were found as a result of other comparisons between groups.

A significant effect on the grammatical accuracy of the EFL learners was also observed. All the four scaffolded groups significantly improved their grammatical accuracy as a result of being exposed to the four scaffolds. More specifically, the hard group outperformed the soft and the virtual groups; the reciprocal group also outperformed the soft group. Other comparisons did not reveal any significant differences.

There were also significant differences between the pronunciation improvements of the learners in this study. The results of the posttest showed that the pronunciation of the learners exposed to any one of the four scaffolding treatments significantly improved. A further analysis of the data revealed that the hard group outperformed the three other groups in their pronunciation improvement.

\section{Conclusion}

Back to the aim of the present study to investigate the role of the four scaffolding techniques known as Hard, Soft, Reciprocal (Traditional) and Technology-mediated (Virtual) in developing the oral communication ability of the Iranian EFL learners, the following conclusions were drawn based on the meticulous study and analysis of the data gathered throughout the research project: 
1) It was concluded that the scaffolding treatments had a significant effect on the speaking ability of the learners. The results of the analyses showed a significant outperformance of the learners, in the four scaffolding groups, in the posttest of speaking.

2) It was made clear that as a result of the scaffolding treatments, the learners showed a significant improvement in their fluency, grammar, lexicon, and pronunciation.

In this study, scaffolding was looked upon as a teaching strategy which provides individualized support based on the learner's ZPD (Chang, Sung, \& Chen, 2002). In the process of scaffolding, a more knowledgeable otherpeers, teacher, technology- provides scaffolds or supports to facilitate the learner's development (Raymond, 2000).

The outcomes of the study have implications for both research and practice in the field of scaffolding pedagogy in EFL learning contexts. Based on the findings of the research, a number of guidelines could be set for the Iranian EFL learners in general and more specifically the Nautical students who study at the IAU-Kharg Island. Implications could also be drawn that can be beneficial to teachers engaged in the teaching of English as a foreign language in general and teaching speaking in particular.

\section{Acknowledgments}

I would like to express my most heartfelt and sincere gratitude to Dr. Seyyed Mohammad Alavi for his encouragement, patience and invaluable supervision and guidance. His kind, generous, constant and thoughtful assistance meant a great deal to me in developing this article.

\section{References}

Bruner, J., \& Olson, D. (1973). Learning through experience and learning through media. Prospects, 3(1), 20-38. http://dx.doi.org/10.1007/BF02196942

Burnkart, G. S. (1998). Spoken language: What it is and how to teach it. Retrieved from $\mathrm{http}: / /$ www.eric.ed.gov/contentdelivery/servlet/ERICServlet?accno=ED433722

Chang, K., Chen, I., \& Sung, Y. (2002). The effect of concept mapping to enhance text comprehension and summarization. The Journal of Experimental Education, 71(1), 5-23. http://dx.doi.org/10.1080/00220970209602054

Chen, C., Toh, S., \& Ismail, W. (2005). Are learning styles relevant to virtual reality? Journal of Research on Technology in Education, 38(2), 123-141.http://dx.doi.org/10.1080/15391523.2005.10782453

de Guerrero, M., \& Villamil, O. S. (2000). Activating the ZPD mutual scaffolding in L2 peer revision. The Modern Language Journal, 84, 51-68.http://dx.doi.org/10.1111/0026-7902.00052

Dehoney, J., \& Reeves, T. (1999). Instructional and social dimensions of class web pages. Journal of Computing in Higher Education, 10(2), 19-41. http://dx.doi.org/10.1007/BF02948721

Donato, R. (1994). Collective scaffolding in second language learning. In J. P. Lantolf (Ed), Vygotskian approaches to second language research (pp. 33-56). London: Ablex Publishing.

Ferris, D. (1998). Students' views of academic aural/oral skills: a comparative needs analysis. TESOL Quarterly, 32, 289-318. http://dx.doi.org/10.2307/3587585

Ferris, D., \& Tagg, T. (1996a). Academic listening/speaking tasks for ESL students: Problems, suggestions, and implications. TESOL Quarterly, 30(2), 297-320. http://dx.doi.org/10.2307/3588145

Ferris, D., \& Tagg, T. (1996b). Academic oral communication needs for EAP learners: What subject-matter instructors actually require. TESOL Quarterly, 30(1), 31-58. http://dx.doi.org/10.2307/3587606

Holton, D., \& Clarke, D. (2006). Scaffolding and metacognition. International Journal of Mathematical Education in Science and Technology, 37(2), 127-143. http://dx.doi.org/10.1080/00207390500285818

Iwashita, N., Brown, A., McNamara, T., \& O’Hagan, S. (2008). Assessed levels of second language speaking proficiency: How distinct? Applied Linguistics, 29(1), 24-49.

Kim, S. (2006). Academic oral communication needs of East Asian international graduate students in non-science and non-engineering fields. English for Specific Purposes, 25, 479-489. http://dx.doi.org/10.1016/j.esp.2005.10.001

Larsen, R. E. (1992). Relationship of learning style to the effectiveness and acceptance of interactive video instruction. Journal of Computer-Based Instruction, 19(11), 17-21. 
Le, P. H. H. (2006). Mediation through the first language: A sociocultural study of group work in Vietnam. RELC Journal, 37(1), 105-121.

Oliver, R., \& Herrington, J. (2003). Exploring technology-mediated learning from a pedagogical perspective. Journal of Interactive Learning Environments, 11(2), 111-126. http://dx.doi.org/10.1076/ilee.11.2.111.14136

Ostler, S. E. (1980). A survey of academic needs for advanced ESL. TESOL Quarterly, 14(4), 489-502. http://dx.doi.org/10.2307/3586237

Palincsar, A. S. (1986). Reciprocal teaching. In teaching reading as thinking. Oak Brook, IL: North Central Regional Educational Laboratory.

Patel, D. S. (2011). Significance of technology-enhanced language learning (TELL) in language classes. Journal of Technology for ELT. Retrieved from https://sites.google.com/site/journaloftechnologyforelt/archive/vol-4/2

Pica, T., \& Doughty, C. (1985). Input and interaction in the communicative language classroom: A comparison of teacher-fronted and group activities. In S. Gass, \& C. Madden (Eds.), Input in second language acquisition. Rowley, MA: Newbury House.

Ragan, T., \& Smith, P. (1996). Soft technologies: Instructional and informational design research. In D. Jonassen (Ed.), Handbook of research for educational telecommunications andtechnology (pp. 541-569). New York: MacMillan.

Raymond, E. (2000). Cognitive characteristics. Learners with mild disabilities. Needham Heights, MA: Allyn \& Bacon, A Pearson Education Company.

Richards, J. C. (1990). Conversational speaking: Approaches to the teaching of conversations. In J. C. Richards (Ed.), The language teaching matrix (pp. 67-85). New York: Cambridge University Press.

Richards, J. C., \& Renandya, W. A. (Eds.). (2002). Methodology in language teaching: An anthology of current practice. Cambridge: Cambridge University Press.

Saye, J. W., \& Brush, T. (2002). Scaffolding critical reasoning about social issues in a multimedia-supported learning environment. Educational Technology Research and Development, 50(3). http://dx.doi.org/10.1007/BF02505026

Storch, N. (2002). Patterns of interaction in L2 pair work. Language Learning, 52(1), 119-158.

Storch, N. (2005). Collaborative writing: Product, process, and students' reflections. Journal of Second Language Writing, 14, 153-173. http://dx.doi.org/10.1016/j.jslw.2005.05.002

Winnips, K., \& McLoughlin, C. (2000). Applications and categorization of software-based scaffolding. In J. Bourdeau \& R. Heller (Eds.), Proceedings of World Conference on Educational Multimedia, Hypermedia, and Telecommunications2000 (pp. 1798-1799). Chesapeake, VA: AACE.

Yelland, N., \& Masters, J. (2007). Rethinking scaffolding in the information age. Computers \& Education, 48(3), 362-382. http://dx.doi.org/10.1016/j.compedu.2005.01.010

\section{Appendix A}

\section{Pretest of Speaking}

How long have been studying here?

How do you travel to and from the island?

Where were you born? Describe your hometown.

Have you gotten your driver's license? When can people apply for it in your country? What are the procedures?

When does a police officer fine a driver? Three situations?

Continue the sentence. Which is your brother? My brother is the boy

Why did you stay up so late last night?

Complete the sentence. If I find a wallet in the street,

Have you visited a foreign country? What is your favorite country and why? 
Why did you decide to choose this field of study?

Please introduce your major to others who might like to go to university.

How long have you lived on this island?

Can you describe the island and the people living here?

How did you feel on the day of your arrival?

What's your best memory of living here?

What would you like to be or do after you get your degree?

\section{Appendix B}

\section{Posttest of Speaking}

Have you already taken your vacation?

What should you learn before you go to a foreign country?

Have you adjusted yourself to the new conditions?

Can you explain about one of the Iranian customs that you like?

Are your courses easy enough for you?

What are you most worried about?

Do you know when the Eifel Tower was built?

Did your roommate tell you to do anything last night?

Do you have any free time here? How do you fill it?

What do you get a loan from the bank for? Do you know the formalities?

Combine the sentences:

That is Ali. I invited him to my birthday.

Mr. Yamini is my teacher. His accent is Kurdish.

Answer the question with I wonder......

When was the conference?

Why is she leaving in a hurry?

Do you know who designed the Eifel Tower?

\section{Copyrights}

Copyright for this article is retained by the author(s), with first publication rights granted to the journal.

This is an open-access article distributed under the terms and conditions of the Creative Commons Attribution license (http://creativecommons.org/licenses/by/3.0/). 